\title{
OXIDATIVE STRESS AND SEED GERMINATION OF WINTER WHEAT
}

\author{
(TRITICUM AESTIWUM L.)
}

\author{
V. KALYTKA, doctor of Science, Professor \\ Yu. KLIPAKOVA, assistant \\ Tavria State Agrotechnological University \\ E-mail: klipakova86@mail.ru
}

\begin{abstract}
The intensity of lipid peroxidation of caryopsis, roots and sprouts of winter wheat and its effect on seed germination and seedling growth were studied. Two years of seed storage decrease its vitality, adversely affecting germination qualities. Sterilization of seeds causes an additional chemical stress, which can be regulated by plant growth regulators (PGR) with antioxidant properties. Anti-stress PGRs are able to reduce the negative impact of prolonged oxidative stress caused by protectants and chemicals during sterilization, especially during heterotrophic type of nutrition. Adaptation of primary roots and sprouts to the conditions of caryopsis germination proceeds differently. In roots it ends with transition to autotrophic nutrition, and sprouts - goes to the stage of formation of the first unfolded leaf regardless of the effect of investigated stress factors. In general, the intensity of oxidative stress in sprouts is double as that in the roots. A strong inverse correlation dependence $(r=-0.908 \div-0.997)$ was determined between malondialdehyde (MDA) and dry matter content in the roots, which should be considered when choosing a combination of protectants and PGR.
\end{abstract}

Key words: lipid peroxidation, caryopsis, roots, winter wheat sprouts, phytopathogens, protectants, growth regulators.

Introduction. Intensive winter wheat varieties have high productivity potential, realization of which requires constant monitoring of the formation of the major structural elements of the crop. Sowing seed qualities and the impact of pathogens and chemicals that are used in the preparation of seeds for sowing are important for the formation of density of plants in the phase of germination. The most common in this sense are different protectants that provide protection of sprouts against diseases and pests in autumn growing season. The developers of these preparations certify a wide range of physiological activity and lack of phytotoxicity on germinating seeds. 
Analysis of recent researches and publications. Seeds of most crops during storage are in cryptobiotic state where there is no vitality, but viability remains through enzyme conservation, membrane integrity, and coherence of potential exchange [4]. A necessary condition for seed germination is the water saturation of the tissues with active oxygen. Respiration rate increases immediately after seed imbibition. The presence of pathogens (biotic stress factors) of chemicals (chemical stress factor) stimulates the formation of reactive oxygen species (ROS), which on one side start the process of germination [10], and the other - inhibit it by enzyme deactivation, violation of membrane integrity and metabolism consistency as a result of lipid peroxidation processes. Intensification of the process of lipid peroxidation is prevented by some plant growth regulators (PGR) with antioxidant properties [12]. These PGRs control homeostasis of reactive oxygen species and secondary products of lipid peroxidation, provide support for prooxidant-antioxidant balance in seed biomembranes, which has a positive effect on the germination and growth of sprouts under the influence of biotic, abiotic and chemical stress factors.

Stress tends to temporarily delay seed germination [5]. Germination is inhibited by stress factors such as toxic substances (oil waste), herbicides, fatty acids, low molecular weight spirits, fungus disease pathogens (Fusarium). Heavy metals (copper) catalyze the formation of free hydroxide and peroxide radicals, accompanied by a significant increase in the content of malondialdehyde (MDA) in the roots of winter wheat sprouts in acidic environment ( $\mathrm{pH} 4.7$ ), compared to seedlings cultured at $\mathrm{pH} 6.2$ [15].

A significant reduction in photosynthetic activity is noted in young (1st and 2nd) leaves of wheat under the influence of chemical (0.2-0.3 M NaCl) and abiotic (drought) stress factors [6].

The use of pesticides for seed treatment inhibits seed germination and growth of embryonic roots of wheat under the conditions of laboratory and field experiments $[16,18]$.

Other research indicates an increase in laboratory and field germination by $0.9-3.6 \%[3,20]$. 
Our previous studies have established stimulating effect of protectants on growth of the primary roots and negative effect on growth of the stem, germination energy, and laboratory germination of one year seeds [9]. The impact share of protectants on laboratory germination reached $82 \%$. Multidirectional impact of protectants on seed germination, root and sprout growth is probably associated with the effect of pesticide stress factor which confirmed a strong inverse correlation $(r=$ - $0.869 \div-0.992$ ) between dry matter content and MDA in the roots and strong direct correlation $(r=0.881-0.989)$ between these parameters in sprouts [8].

The following additional stress factors such as soil pathogens and pests (exogenous biotic stress factors), unfavorable hydrothermal conditions (abiotic stress factor) affect germinating seeds and sprouts in the field. All these factors cause further intensification of lipid peroxidation processes and the uncontrolled development of oxidative stress.

The use of amistar trio fungicide for the treatment of vegetating plants reduced the rate of dry matter accumulation in the leaves in the first two weeks after treatment by reducing the intensity of photosynthesis and chlorophyll content [7].

Unlike gradual stress eruptions that delay germination, "shock" influences cause the opposite effect $[1,5]$.

The contribution of each of the examined stress factors in the development of oxidative stress is different, but research in this aspect is almost absent. The purpose of our research was to determine the effect of certain stress factors and their combined effect on the development of oxidative stress in germinating seeds, roots and sprouts and to justify the directions of sprout adaptation to adverse environmental conditions.

Materials and methods. Research was carried out in the "Laboratory of monitoring of soil and crop product quality" of the Research Institute of agricultural technologies and ecology of Tavria State Agrotechnological University in 2014-2015. Seeds of Antonovka winter wheat (Triticum aestivum L.) cultivar $\left(\mathrm{R}_{1}\right)$ were used for the research. Originator - "Selection and Genetics Institute - National Center of Seed and Cultivar Studies" (Ukraine). Variety is in the register cultivars of Ukraine since 
2008, erythrosperum type. Plant height is $92-96 \mathrm{~cm}$, has high productive bushiness, high winter hardiness and drought resistance, disease resistance. Weight of 1000 grains is 36.2-44.4 g, protein content - 12.5-13.8\%, wet gluten - 28.4-33.6\%. Recommended for cultivation in Steppe and Lisosteppe zones of the country.

Seeds taken for the experiment, were stored in insurance funds for two years and were infected by fungi. Part of the seeds was sequentially sterilized by $1 \%$ solution of potassium permanganate ( $3 \mathrm{~min}$.), $96 \%$ solution of ethanol ( $2 \mathrm{~min}$.), $0.1 \%$ solution of silver nitrate (1 min.) [11]. After each stage of sterilization seeds were washed with sterile distilled water.

Unsterilized and sterilized seeds were treated with the solution of Raksil Ultra protectant $(0.25 \mathrm{l} / \mathrm{t})$ [17] and plant growth regulator AKM (0.33 1/t) [19] before germination at the rate of 10 liters of working solution per 1 ton of seeds.

Four treatment variants were evaluated in an experiment with unsterilized seeds: V1 - water treatment (Control 1), V2 - AKM growth regulator treatment, V3 - Raksil Ultra protectant treatment, V4 - treatment with a mixture of AKM and Raksil Ultra. Treatment variants V5 (Control 2), V6, V7, V8 were used for sterilized seeds in the same sequence.

Seeds were germinated in Petri dishes (100 seeds each) on moist filter paper in the thermostat at $20 \pm 2{ }^{0} \mathrm{C}$ to $\mathrm{BBCH} 07$ stage without light, then - with light. The experiment was carried out in four biological replications, three analytical in each.

Samples for analysis were taken at the same time of day for BBCH stages 00, $03,05,07,09,10,11$. The intensity of lipid peroxidation (LP) was evaluated by the content of malondialdehyde in weevil, roots and seedlings, which was determined by the spectrophotometric method (UNICO 2800 UV/VIS) by reaction with 2thiobarbituric acid [13] and counted to dry matter (DM). The mass of dry matter was determined by gravimetric method, germination energy and laboratory germination by conventional techniques [2].

In the work the original Raksil Ultra 120 FS preparation by "Bayer CropScience" company (Germany), ionol (China), dimethyl sulfoxide, PEG 400, PEG 1500 (Ukraine), Pro Analysi and Purissimum analytical reagents were used. The 
results were evaluated by variational statistics method using MS Office 2010 and Agrostat New software. The differences between the variants wereevaluated using LSD test with minimum significance level $\mathrm{R} \leq 0.05$.

Results and discussion. Dry winter wheat seeds that were in cryptobiosis state for two years had a very low intensity of oxidative metabolism, and MDA content did not exceed $5.2 \mathrm{nmol} / \mathrm{g}$ DM (Table 1). It should be noted that the content in one-year dry seeds was three times higher $(15.5 \mathrm{nmol} / \mathrm{g} \mathrm{DM})$ [8]. This indicates a reduction in seed viability during storage, which adversely affected its germination. Thus, germination energy declined by $3.0 \mathrm{pp}$, and laboratory germination by $5.0 \mathrm{pp}$ (Table 2) relative to similar indices for one-year seeds.

1. MDA content in winter wheat weevil during germination and sprout growth, nmol/g DM

\begin{tabular}{|c|c|c|c|c|c|c|c|c|}
\hline \multirow{2}{*}{ Variant } & \multicolumn{7}{|c|}{ Stage of development, BBCH code } \\
\cline { 2 - 8 } & 00 & 03 & 05 & 07 & 09 & 10 & 11 \\
\hline $1(\mathrm{C} 1)$ & 5.16 & 6.89 & 7.31 & 11.03 & 11.36 & 9.50 & 3.85 \\
\hline 2 & 2.76 & 6.64 & 5.81 & 7.91 & 11.09 & 8.46 & 4.61 \\
\hline 3 & 4.15 & 3.46 & 9.76 & 6.20 & 5.35 & 4.49 & 2.91 \\
\hline 4 & 3.53 & 4.62 & 11.27 & 8.25 & 7.29 & 5.89 & 4.80 \\
\hline $5(\mathrm{C} 2)$ & 5.82 & 7.43 & 10.07 & 11.73 & 13.60 & 10.56 & 3.78 \\
\hline 6 & 6.54 & 4.51 & 6.86 & 7.31 & 5.26 & 4.11 & 4.77 \\
\hline 7 & 7.81 & 10.94 & 12.37 & 8.10 & 10.76 & 7.24 & 4.05 \\
\hline 8 & 6.65 & 8.05 & 13.52 & 5.42 & 9.41 & 6.28 & 4.84 \\
\hline \begin{tabular}{l}
$|c|$ \\
\hline
\end{tabular} & 0.13 & 0.15 & 0.14 & 0.15 & 0.20 & 0.18 & 0.24 \\
\hline A (sterilization) & & & & & & & \\
\hline B (protectant) & 0.05 & 0.16 & 0.13 & 0.12 & 0.16 & 0.06 & 0.07 \\
\hline C (PGR) & 0.13 & 0.09 & 0.09 & 0.16 & 0.16 & 0.15 & 0.10 \\
\hline
\end{tabular}

When treating two-year seeds by protectant and PGR there was a tendency to reduce germination energy by 2.7-3.0 pp. Germination decreased by 2 pp under AKM action and increased by 6.0 and $3.7 \mathrm{pp}$ - under Raksil Ultra and its mixture with AKM action. Thus, the trend in change of laboratory germination for two-year and one-year seeds is kept, especially under the influence of protectant [9]. 
Number of seeds affected by fungal diseases (Table 2) gives reason to believe that unsterilized seeds of control variant (V1) and treated with AKM (V2) are predominantly exposed to biotic stress factors. Other variants of unsterilized and all variants of sterilized seeds are exposed to chemical stressors.

\section{Sowing qualities of winter wheat seeds}

\begin{tabular}{|c|c|c|c|}
\hline Variant & $\begin{array}{c}\text { Germination } \\
\text { energy, }\end{array}$ & $\begin{array}{c}\text { Laboratory } \\
\text { germination, \% }\end{array}$ & $\begin{array}{c}\text { Number of } \\
\text { affected seeds, } \\
\text { pcs. }\end{array}$ \\
\hline \multicolumn{5}{|c|}{ Unsterilized seeds } \\
\hline $1(\mathrm{C} 1)$ & 91.7 & 83.0 & 27 \\
\hline 2 & 89.0 & 81.0 & 3 \\
\hline 3 & 89.0 & 89.0 & 2 \\
\hline 4 & 88.7 & 86.7 & -- \\
\hline \multicolumn{4}{|c|}{ Sterilized seeds } \\
\hline 5 (C2) & 64.3 & 75.3 & -- \\
\hline 6 & 60.7 & 85.0 & -- \\
\hline 7 & 54.0 & 66.3 & \\
\hline 8 & 53.7 & 68.0 & \\
\hline
\end{tabular}

The intensity of lipid peroxidation in sterilized untreated weevil (V5) was significantly higher compared with unsterilized (B1) (Table 1) due to the prevalence of stress influence of chemical sterilization. This tendency is traced to the stage of the second leaf (BBCH 11) when MDA content is leveled, probably due to weevil adaptation to the conditions of germination. It should be noted that adaptation of unsterilized weevils to the conditions germination occurs faster than for sterilized, but in both cases it happens during the period of autotrophic nutrition. High levels of MDA in weevil delay germination, especially for sterilized weevils and reduce laboratory germination (Table 2).

Under AKM action MDA content in dry sterilized weevil (V6) exceeded the figure of unsterilized weevil (V2) by 2.4 times. At the stage of full weevil imbibition 
(BBCH 03) AKM begins to show strong antioxidant effect, the intensity of lipid peroxidation in sterilized weevil decreases, and until the end of the experiment is at a lower level than in unsterilized. In addition, AKM promotes more rapid adaptation of sterilized caryopsides to germination conditions and reduces MDA variability during development stages. In general, AKM antioxidant effect appears more effectively in sterilized weevils compared to unsterilized, which significantly affects the laboratory germination sterilized, treated by AKM, caryopsides (V6), increasing it by 9.7 percentage points compared to untreated (V5) (Table 2). Thus, AKM more effectively inhibits impact of chemical stress factor during caryopsis sterilization than of biotic in unsterilized weevil. This should be considered when growing crops on soils contaminated by chemicals.

Unsterilized seed treatment eliminates biotic stress factor, but causes the development of pesticide stress. "Shock" action of protectant causes the lipid peroxidation process intensification at the stage of embryonic root emergence $\mathrm{BBCH}$ 05) (Table 1), then MDA level reduces to the original. Due to faster adaptation of unsterilized weevils to the conditions of germination, laboratory germination increases by 6 percentage points compared to nontreated (Table 2). Under protectant's actions on sterilized seeds, pesticide stress is added to chemical stress during sterilization, causing peroxidation processes intensification in weevil during the stage of embryonic root imbibition and in transition to autotrophic nutrition. Uncontrolled oxidative stress causes inhibition of germination of sterilized treated weevils and seedling growth. Germination energy and laboratory germination decrease respectively by 35.0 and 22.7 percentage points compared to unsterilized treated seeds and by 10.3 and 9.0 percentage points compared to nontreated sterilized seeds (Table 2).

Seed sterilization (20.2\%) (chemical stress) and interaction of chemical (sterilization) and pesticide (protectants) stresses (19.9\%) with significant (17.2\%) impact of PPP had the greatest influence on the content of MDA in germinating weevils. 
Significant influence of investigated factors in loss of dry matter by during sprout heterotrophic seedling supply type was not detected (Table 3). The growth of influence was observed only during autotrophic type of nutrition, but the proportion of influence was essential only for AKM (55.3\%) and interaction of pesticide and biotic factors $(23.3 \%)$.

The intensity of lipid peroxidation in embryonic roots in imbibition stage (BBCH 05) varied not only in size but also in the dynamics of MDA content at the emergence of etiolated coleoptile. At the stage $05 \mathrm{BBCH}$ the highest content of MDA established under the action of pesticide stress factor in unsterilized seeds (V3 and V4).

During the emergence of etiolated coleoptile (BBCH 07) under the effect of biotic stress factor lipid peroxidation intensity in sprout roots was the largest and exceeded the figure for other variants of the trial. Thus, MDA content in the roots of unsterilized seeds (V1 and V2) exceeded the figure for sterilized seeds (V5 and V6) by $60 \%$, indicating a decrease in the intensity of oxidative metabolism at sterilization.

\section{Dry matter weight of one winter wheat weevil during germination and sprout growth, mg}

\begin{tabular}{|c|c|c|c|c|c|c|c|c|}
\hline \multirow{2}{*}{ Variant } & \multicolumn{7}{|c|}{ Development stage, BBCH code } \\
\cline { 2 - 8 } & 00 & 03 & 05 & 07 & 09 & 10 & 11 \\
\hline \multicolumn{7}{|c|}{ Unsterilized seeds } \\
\hline $1(\mathrm{C} 1)$ & 38.07 & 38.33 & 37.37 & 32.42 & 25.13 & 20.64 & 9.05 \\
\hline 2 & 37.5 & 38.27 & 37.55 & 32.94 & 28.63 & 15.66 & 12.07 \\
\hline 3 & 38.13 & 38.33 & 36.25 & 31.62 & 26.5 & 20.20 & 12.60 \\
\hline 4 & 38.2 & 38.22 & 36.15 & 33.20 & 25.46 & 20.70 & 14.09 \\
\hline $5(\mathrm{C} 2)$ & 38.04 & 38.27 & 37.17 & 33.01 & 26.08 & 19.20 & 10.29 \\
\hline 6 & 38.08 & 38.23 & 37.30 & 33.40 & 29.32 & 20.64 & 12.19 \\
\hline 7 & 38.08 & 38.37 & 36.11 & 33.40 & 25.67 & 17.65 & 12.69 \\
\hline 8 & 38.12 & 38.16 & 36.16 & 33.08 & 28.42 & 18.45 & 11.41 \\
\hline $\begin{array}{l}\text { LSD } \\
\text { A (sterilization) }\end{array}$ & 0.45 & 0.67 & 0.55 & 0.80 & 0.46 & 0.99 & 0.81 \\
\hline B (protectant) & 0.53 & 0.34 & 0.40 & 0.20 & 0.50 & 0.36 & 0.37 \\
\hline C (PGR) & 0.30 & 0.38 & 0.26 & 0.23 & 0.38 & 0.30 & 0.34 \\
\hline
\end{tabular}


This trend continues under the action of pesticide stress factor (V3 and V7) but the difference is $40 \%$. Dynamics of MDA content in roots of sprouts during heterotrophic type of nutrition gives reason to assert that biotic stress inhibits the germination of seeds, while pesticide - stimulates it.

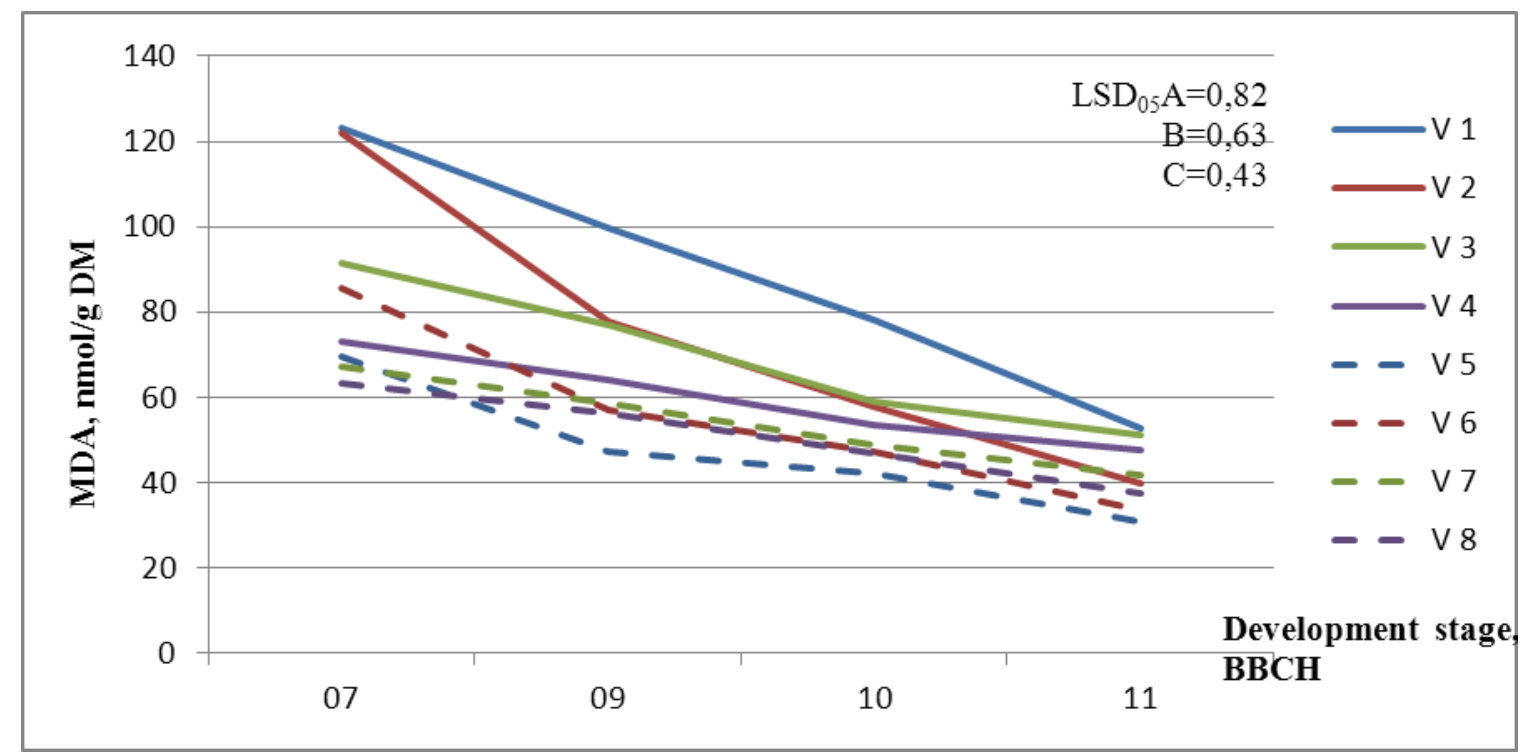

\section{Fig.1. Dynamics of MDA content in the roots of winter wheat sprouts}

Transition to autotrophic nutrition type $(\mathrm{BBCH} 09)$ is accompanied by a significant reduction of MDA in sprout roots of all variants of the experiment (by 19$36 \%$ ) except for variants of seed treatment with protectant and its mixture with AKM (by 11-16\%). Characteristically, the impact of PGR on the intensity of lipid peroxidation in primary roots weakens, especially for sterilized seeds. Reduction of MDA content during the studied period of sprout autotrophic nutrition suggests adaptation of the roots to existing stress factors. Lipid peroxidation intensity at the stage of the first expanded leaf emergence can be considered a normal reaction of the roots to oxidative stress in initial growth stages of the sprout. The effect of investigated factors on root growth was the highest for biotic stress factor, its share reached $65.2 \%$. Pesticide stress factor had considerably less impact (9.3\%) and plant growth regulator was immaterial $(3.3 \%)$.

The intensity of dry matter synthesis in the roots of sprouts during heterotrophic nutrition is low and its lowest amount is recorded under the actions of pure AKM and 
its mixture with protectant in case of seed sterilization (Table 4). Transition to autotrophic nutrition type (BBCH 09) is accompanied by an increase in dry matter synthesis in the roots by 2.6 - 3.5 times, compared to the stage of etiolated sprout.

\section{Dry matter mass of roots of one winter wheat sprout, mg}

\begin{tabular}{|c|c|c|c|c|}
\hline \multirow{2}{*}{ Variant } & \multicolumn{5}{|c|}{ Development stage, BBCH code } \\
\cline { 2 - 5 } & 07 & 09 & 10 & 11 \\
\hline \multicolumn{5}{|c|}{ Unsterilized seeds } \\
\hline $1(\mathrm{C} 1)$ & $\mathbf{1 . 8 1}$ & $\mathbf{3 . 2 6}$ & $\mathbf{6 . 8 6}$ & $\mathbf{9 . 7 1}$ \\
\hline 2 & 1.23 & 3.47 & 6.92 & 9.28 \\
\hline 3 & 1.67 & 4.78 & 5.49 & 9.50 \\
\hline 4 & 1.91 & 4.88 & 7.46 & 9.65 \\
\hline \multicolumn{5}{|c|}{ Sterilized seeds } \\
\hline $5(\mathrm{C} 2)$ & $\mathbf{1 . 4 7}$ & $\mathbf{4 . 2 5}$ & $\mathbf{9 . 7 0}$ & $\mathbf{1 0 . 0 0}$ \\
\hline 6 & 1.25 & 3.39 & 6.45 & 10.04 \\
\hline 7 & 1.54 & 3.13 & 8.45 & 9.68 \\
\hline 8 & 1.27 & 4.42 & 8.60 & 11.47 \\
\hline $\begin{array}{l}\text { LSD } \\
\text { A (sterilization) }\end{array}$ & 0.08 & 0.19 & 0.18 & 0.25 \\
\hline B (protectant) & 0.11 & 0.10 & 0.08 & 0.20 \\
\hline C (PGR) & 0.08 & 0.06 & 0.14 & 0.20 \\
\hline
\end{tabular}

Dynamics of dry matter in the roots during autotrophic nutrition is almost the same, regardless of the actions of investigated stress factors and at the stage of the first expanded leaf $(\mathrm{BBCH} 11)$ no significant difference between the variants of the experiment was found. The exception applies to the variant of treating sterilized seed by a mixture of AKM and Raksil Ultra where dry matter mass of the roots was higher relative to other variants in average by $22 \%$. This is confirmed by share of impact of interaction of these factors, which is $51.5 \%$, while the impact of other factors does not exceed $24.8 \%$. So, for the non-infected seeds, the use of protectants and PGR stimulates the growth of the root system, which is extremely important for wintering of winter crops and forming resistance to adverse hydrothermal conditions during spring-summer growing season. However, when choosing a combination of protectant and PGR, it is necessary to pay attention to phytotoxicity of protectant and antioxidant properties of PGR that control the intensity of lipid peroxidation in 
germinating seeds, since a strong inverse correlation $(r=-0.908 \div-0.997)$ is established between the level of MDA and DM of the roots.

Intensity of lipid peroxidation in etiolated winter wheat sprouts (BBCH 07) is quite high, with the exception of variants 4, 7, 8, where Raksil Ultra was used for pretreatment of sterilized and non-sterilized seeds (Fig. 2).

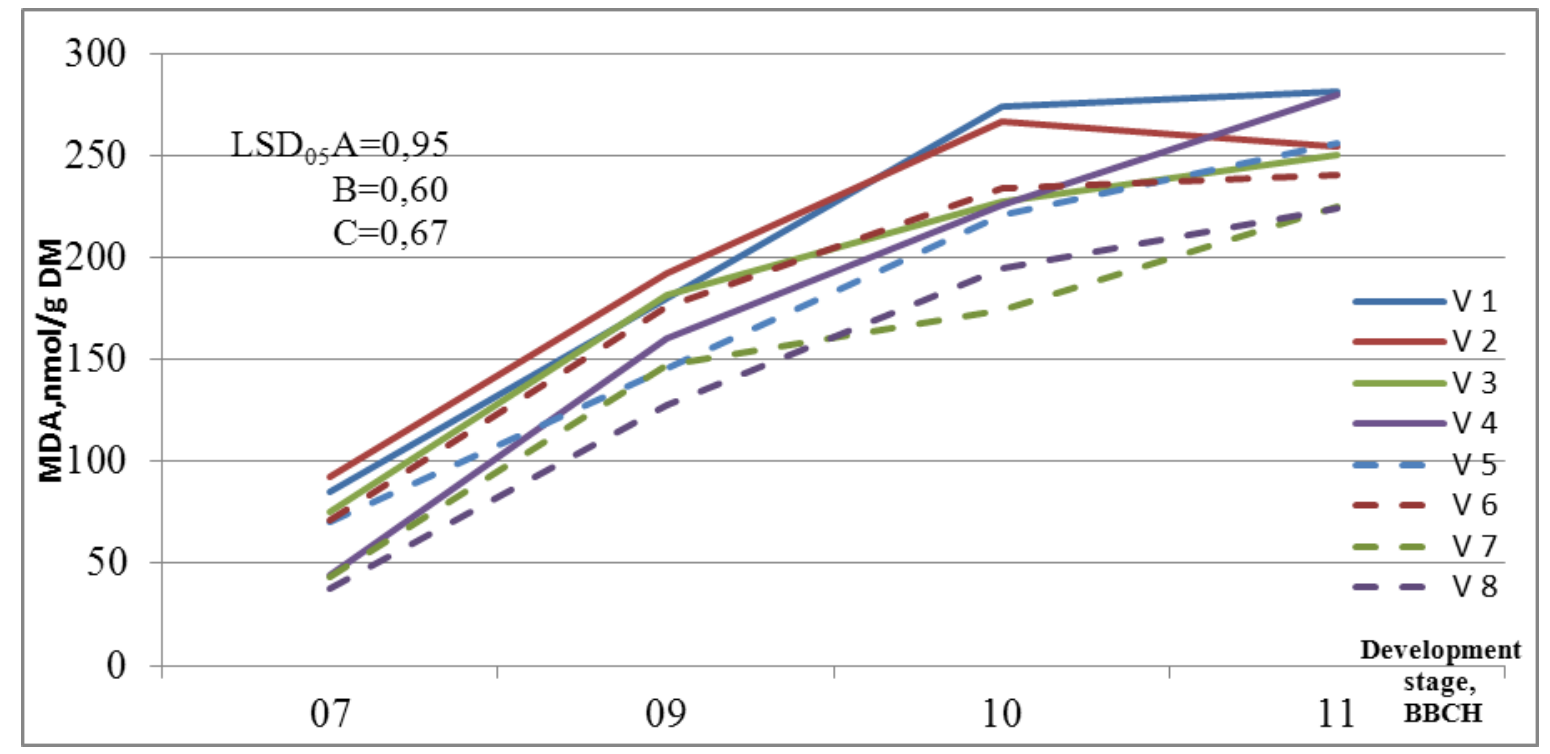

Fig.2. Dynamics of MDA content in winter wheat sprouts

With the transition to autotrophic nutrition at the stage BBCH 09, MDA content in sprouts rose by 2.1 - 3.6 times compared to the previous stage of development. The greatest intensification of peroxide processes (by 3.4 - 3.6 times) was caused by pesticide stress factor (V4, V7 and V8). It should be noted that at this stage of development attenuation of peroxide processes (Figure 1) was observed in the roots of sprouts as a result of adaptation of roots to external conditions. Thus, photosynthesis induces the formation of additional quantities of reactive oxygen species and oxidative stress rapid development, especially for the actions of pesticide stress factor. Further, lipid peroxidation intensity in sprouts grew and MDA content at the stage of first expanded leaf exceeded this figure for etiolated coleoptile by 3.3 6.3 times. In addition, adaptation of sprout to external conditions was observed only for the actions of AKM for unsterilized seeds (V2). Therefore, in order to clarify the mechanisms of sprout adaptation to external conditions of the autumn growing season it is necessary to continue the research until the stage of early tillering (BBCH 20). 
Sterilization (55.2\%) and seed treatment (42.4\%) had the largest share of influence on the MDA level in the sprouts. Effect of other factors was unreliable.

Increase in sprout dry matter mass during heterotrophic nutrition was negligible and no significant difference between the variants was determined (Table 5).

\section{Dry matter mass of one winter wheat sprout, mg}

\begin{tabular}{|c|c|c|c|c|}
\hline \multirow[t]{2}{*}{ Variant } & \multicolumn{4}{|c|}{ Development stage, BBCH code } \\
\hline & 07 & 09 & 10 & 11 \\
\hline \multicolumn{5}{|c|}{ Unsterilized seeds } \\
\hline $1(\mathrm{C} 1)$ & 0.85 & 4.62 & 7.95 & 12.90 \\
\hline 2 & 0.75 & 3.92 & 7.83 & 10.55 \\
\hline 3 & 0.89 & 4.42 & 7.55 & 11.29 \\
\hline 4 & 0.93 & 3.87 & 7.35 & 9.87 \\
\hline \multicolumn{5}{|c|}{ Sterilized seeds } \\
\hline $5(\mathrm{C} 2)$ & 1.02 & 4.51 & 8.32 & 12.80 \\
\hline 6 & 0.73 & 3.49 & 7.94 & 11.75 \\
\hline 7 & 0.89 & 3.81 & 7.47 & 10.83 \\
\hline 8 & 0.98 & 4.33 & 7.83 & 12.23 \\
\hline $\begin{array}{l}\text { LSD }_{05} \\
\text { A (sterilization) }\end{array}$ & 0.01 & 0.23 & 0.37 & 0.34 \\
\hline B (protectant) & 0.02 & 0.10 & 0.32 & 0.50 \\
\hline $\mathrm{C}$ (PGR) & 0.02 & 0.06 & 0.24 & 0.19 \\
\hline
\end{tabular}

With the transition to autotrophic nutrition type (BBCH 09) DM mass of the sprout increased by 4.2 - 5.4 times, compared to the previous stage of development (Table 5). The lowest sprout DM mass increase was observed for the action of pesticide stress factor for sterilized (V 8) and unsterilized (V 3) seeds. Similar trends in the dynamics of sprout DM mass are tracked to the stage of formation of the first expanded leaf $(\mathrm{BBCH} 11)$. Overall for the whole studied period of autotrophic nutrition, a decline in the mass of sprouts under the influence of pesticide stress factor was observed. A similar result was documented by Spanish scientists, but for tomato and watermelon sprouts under thermal stress [14]. Therefore, protectant (18.0\%), PGR - $(20.8 \%)$ and the interaction of these factors (24.4\%) had a significant impact on DM mass of sprouts. A strong direct correlation $(r=0.906-0.980)$ was 
established between the DM and MDA content in sprouts, which requires more detailed study of the impact of PGR on the development of oxidative stress and intensity of photosynthesis in sprouts of young plants of winter wheat.

\section{Discussion}

1. Intensity of oxidative metabolism and vitality of winter wheat seeds decrease during storage, which negatively affects their sowing qualities.

2. Unsterilized two-year old seeds react on application of treater and PGR by reducing germination energy and increasing laboratory germination.

3. Intensity of lipid peroxidation in sterilized weevils significantly increases compared to unsterilized, delaying germination; the difference in content MDA is leveled only during autotrophic seedling nutrition.

4. Treatment of sterilized weevils by AKM causes short term "shock" oxidative stress that causes rapid adaptation to germination conditions and increases laboratory germination by 9.7 percentage points compared to untreated weevils.

5. Unsterilized caryopsides treatment removes biotic stress factor and functions similarly to PGR in case of weevil sterilization. uncontrolled oxidant stress develops when treating sterilized weevils and causes the largest decrease in germination energy (35.0 percentage points) and laboratory germination (22.7 percentage points).

6. The maximum intensity of lipid peroxidation is observed at the embryonic stage of root emergence and etiolated coleoptile emergence for the actions of pesticide stress factor.

7. Transition to autotrophic nutrition type is accompanied by adaptation of primary roots to the conditions of germination, the duration of which is highly dependent on the depth of seed sowing in the field and the length of heterotrophic period of nutrition, as evidenced by the growth dynamics of dry matter in the roots of sprouts. When choosing a combination of protectant and PGR, phytotoxicity of protectant and antioxidant properties of PGR should be considered.

8. Intensity of oxidative stress in wheat sprouts in contrast to the roots increases to the stage of the first expanded leaf, as evidenced by increased by 3.3-6.3 times MDA content at this stage relative to its value at the stage of etiolated 
coleoptile. Sprout adaptation to the conditions of growth is much slower than of the root, which should be considered in the field, especially during the later sowing terms. Pesticide stress factor reduces the growth of dry matter of the sprout, probably by inhibiting photosynthesis, requiring complex studies of the impact of PGR and protectants on the development of oxidative stress and intensity of photosynthetic processes for the action of various stress factors.

\section{REFERENCES}

1. Batsmanova, L., Taran, N., Kosyan, A. (2014). Oxidation stress is adaptative reaction inductor of winter wheat plants. Journal Agriculture (Pol'nohospodárstvo), 60 (2), 70-76. doi: 10.2478/agri-2014-0008.

2. Filatov, V. I., Bazdyreva, G. I., Safonov, A. F. (2002). Praktikum po agrobiologicheskim osnovam proizvodstva, hraneniya i pererabotki produkcii rastenievodstva [Workshop on agrobiological basics of production, storage and processing of crop products]. Moscow, Russia: Ear, 624.

3. Gao, J. R., Wang, H. G., Li, X. F., Bao, Y. G., Feng, D. S. (2014). Factors influencing seedling emergence from immature embryos of winter wheat and the transplantation in summer field. Bulgarian Journal of Agricultural Science, 5, $1102-1108$.

4. Henckel, P. A. (1982). Physiology of plant heat- and drought resistance. Moscow, Russia: Science, 280.

5. Heydecker, W. (1977). Stress and seed germination: the agronomic point of view: http://agris.fao.org/aos/records/US201302404010.

6. Ivanov, A. A. (2013). Sovmestnoe dejstvie vodnogo i solevogo stressov na fotosinteticheskuyu aktivnost' list'ev pshenicy raznogo vozrasta [The combined action of water and salt stress on photosynthetic activity of different aged leaves of wheat]. Physiology and biochemistry of cultivated plants, 45 (2), 155-162.

7. Ivanov, A. A., Shabanova, N. I., Dunaeva, Yu. S., Kosobryuhov, A. A. (2013). Uvelichenie prodolzhitel'nosti zhizni list'ev pshenicy pri obrabotke rastenij fungicidom [Increase in duration of life of wheat leaves after treatment of plants with fungicide]. Physiology and biochemistry of cultivated plants, 45 (2), 164-171.

8. Kalytka, V. V., Klipakova, Yu.O. (2016). Intensivnist' perekisnogo okislennya lipidiv pri prorostanni nasinnya pshenici ozimoï (Triticum aestivum L.) za diï protrujnikiv i regulyatoriv rostu [ Intensity of peroxide oxidation of lipids during winter wheat seed germination (Triticum aestivum L.) under effect of seed treaters and growth regulators]. Ukrainian Black Sea region agrarian science, 1(88), 81-91.

9. Kalytka, V.V., Klipakova, Yu.O., Zolotukhina, Z. V. (2016). Vpliv regulyatora rostu roslin ta riznokomponentnih protrujnikiv na prorostannya nasinnya pshenici ozimoï (Triticum aestivum L.) [Influence of growth regulator in combination with compound treatment products upon seed germination of winter wheat (Triticum aestivum L.)]. Scientific Herald of NUBIP, “Agronomy” series, 235, 24-33. 
10. Khan, A. (1977). Physiology and biochemistry of seed dormancy and germination. Geneva New York, 495.

11. Kosakivska, I. V., Babenko, L. M., Skaterna, T.D., Ustinova, A.Yu. (2014). Vpliv gipo- i gipertermiï na aktivnist' lipoksigenazi, vmistu pigmentiv i rozchinnih bilkiv u prorostkah pshenici ozimoï sortu YAtran' 60 [The influence of hypo- and hyperthermia in lipoxygenase activity, content of pigments and soluble protein in winter wheat sprouts of Yatran 60 variety]. Plant physiology and genetics, 46, (3), 212-220.

12. Mitteler, R. (2002). Oxidative stress, antioxidants and stress tolerance. Trends Plant Science, 7 (9), 405-410. http://dx.doi.org/10.1016/S 1360-13601385(02)02312-9.

13. Musienko, M. M., Parshikova, T. V., Slavny, P. S. (2001). Spektrofotometrichni metodi $\mathrm{v}$ praktici fiziologiï, biohimiï ta ekologiï roslin [Spectrophotometric methods in the practice of physiology, biochemistry and ecology of plants]. Kyiv, Ukraine: Phytosociocenter, 200.

14. Rivero, R. M., Ruiz, J. M., Garsia, P. C., Lopez-Lefebre, L. R., Sanchez, E., Romero, L. (2000). Resistance to cold and heat stress: accumulation of phenolic compounds in tomato and watermelon plants. Plant Science, 160(2), 315-321. http://dx.doi.org/10.1016/S0168-9452(00)00395-2.

15. Ryazanova, M. E., Batsmanova, L. M., Kovalenko, M.S., Mikhalska, L.M., Shvartau, V.V. (2015). Vpliv ioniv midi ta $\mathrm{rN}$ seredovishcha na antioksidantnu aktivnist' u tkaninah koreniv prorostkiv ozimoï pshenici [Influence of copper ions and $\mathrm{pH}$ on antioxidant activity in the tissues of roots sprouts of winter wheat]. Plant physiology and genetics, 47(6), 497-503.

16. Tasneem, R., Bafna, A. \& Maheshwari, R.S. (2013). Harmful effects of Fungicide Treatment on Wheat (Triticum aestivum L.) Seedlings. International Research Journal of Environment Sciences, 2(8), 1-5.

17. Yashchuk, V. U., Vashchenko, V. M., Krivosheya, R. M., Tsybulnyak, Yu. O., Koretsky, A. P. (2016). Perelik pesticidiv i agrohimikativ, dozvolenih do vikoristannya $\mathrm{v}$ Ukraïni [List of pesticides and agrochemicals permitted for use in Ukraine]. Kyiv, Ukraine: Univest Media 1024 p.

18. Yurchenko, A. I. (2009). Optimizaciya elementiv tekhnologiï viroshchuvannya visokoyakisnogo nasinnya ozimoï pshenici v umovah Central'nogo Lisostepu Ukraïni [Optimization of growing technology elements of high-quality seeds of winter wheat in the conditions of Central Lisosteppe of Ukraine]. Kyiv, Ukraine: $17 \mathrm{p}$.

19. Zaslavsky, O. M., Kalytka, V. V., Malahova, T. O. (2005). Antioxidant composition "AOK-M" for presowing treatment of seeds of agricultural crops. Patent 10460 of Ukraine, MKN7 A 01C1/06, A01N 31/14. № 20041210460; declared 20.12.2004; published 15.08.2005, № 8.

20. Zhang, Y. J., Zhang, X., Chen, C.J., Zhou, M.G., Wang, H.C. (2010). Effects of fungicides JS399-19, azoxystrobin, tebuconazloe and carbendazim on the physiological and biochemical indices and grain yield of winter wheat. Pesticide Biochemistry and Physiology, 98 (2), 151-157. http://dx.doi.org/10.1016/ j.pestbp.2010.04.007. 


\title{
ОКСИДАНТНИЙ СТРЕС І ПРОРОСТАННЯ НАСІННЯ ПШЕНИЦІ ОЗИМОї (TRITICUM AESTIWUM L.)
}

\author{
В. Калитка, Ю. Кліпакова
}

\begin{abstract}
Анотація. Досліджено інтенсивність перекисного окиснення ліпідів зернівки, коренів $і$ паростків пшенищі озимої та його вплив на проростання насіння i ріст проростка. При зберіганні насіння протягом двох років його життєздатність зменшується, що негативно впливає на посівні якості. Стерилізація насіння викликає додатковий хімічний стрес, регулювати який можуть регулятори росту рослин (РРР) з антиоксидантними властивостями. Зменшити негативний вплив тривалого оксидантного стресу, викликаного протруйниками і хімічними речовинами при стерилізачії, здатні антистресові РРP, особливо в період гетеротрофного типу живлення. Адаптація первинних коренів $i$ паростків до умов проростання зернівок протікає по різному. $B$ коренях вона закінчується з переходом до автотрофного типу живлення, а в паростках - продовжується до стадії формування першого розгорнутого листка незалежно від дї досліджуваних стрес-факторів. $B$ иілому інтенсивність оксидантного стресу в паростках два рази перевищує ї в коренях. Між умістом МДА $i$ СР в коренях встановлена сильна обернена корелячійна залежність ( $r=-0,908 \div-0,997)$, що слід враховувати при виборі комбінації протруйника і РРP.
\end{abstract}

Ключові слова: перекисне окиснення ліпідів, зернівки, корені, паростки пшениці, фітопатогени, протруйники, регулятори росту.

\section{ОКСИДАНТНЫЙ СТРЕСС И ПРОРОСТАНИЕ СЕМЯН ПШЕНИЦЫ ОЗИМОЙ (TRITICUM AESTIWUM L.)}

\section{В. Калитка, Ю. Клипакова}

Аннотация. Исследована интенсивность перекисного окисления липидов зерновки, корней и ростков пшенищы озимой и его воздействие на прорастание семян и рост проростка. При хранении семян на протяжении двух лет их жизнеспособность уменьшается, что негативно влияет на посевные качества. Стерилизачия семян вызывает дополнительный химический стресс, регулировать который могут регуляторы роста растений (РPР) c антиоксидантными свойствами. Уменьшить негативное влияние длительного оксидантного стресса, вызванного протравителями $и$ химическими веществами при стерилизачии, способны антистрессовые РРР, особенно в период гетеротрофного типа питания. Адаптация первичных корней и ростков к условиям прорастания зерновок протекает по-разному. В корнях она заканчивается с переходом к автотрофному типу питания, а в ростках продолжается до стадии формирования первого развернутого листка 
независимо от действия исследуемых стресс-факторов. $B$ иелом интенсивность оксидантного стресса в ростках два раза превышает её в корнях. Между содержанием малонового диальдегида (МДА) и сухим веществом в корнях установлена сильная обратная корреляционная зависимость $(r=-0,908 \div-0,997)$, что следует учитывать при выборе комбинации протравителя и РРР.

Ключевые слова: перекисное окисление липидов, зерновки, корни, проростки пшеницы, фитопатогены, протравители, регуляторы роста. 